\title{
Urbanization, State Formation, and Cooperation: A Reappraisal
}

\section{Citation}

Jennings, Justin, and Timothy K. Earle. 2016. “Urbanization, State Formation, and Cooperation: A Reappraisal." Current Anthropology 57 (4) (August): 474-493. doi:10.1086/687510.

\section{Published Version}

doi:10.1086/687510

\section{Permanent link}

http://nrs.harvard.edu/urn-3:HUL.InstRepos:34390100

\section{Terms of Use}

This article was downloaded from Harvard University's DASH repository, and is made available under the terms and conditions applicable to Open Access Policy Articles, as set forth at http:// nrs.harvard.edu/urn-3:HUL.InstRepos:dash.current.terms-of-use\#OAP

\section{Share Your Story}

The Harvard community has made this article openly available.

Please share how this access benefits you. Submit a story.

\section{Accessibility}


Ur, Jason A. 2016. Commentary to Jennings and Earle, "Urbanization, State Formation, and Cooperation: A Reappraisal". Current Anthropology 57 (4):487-488.

I am delighted to see a particularly strong wedge being driven between arbitrarily-fused settlement types ("the city") and political formations ("the state"). This bond is a legacy of one of the most influential articles ever written, V. Gordon Childe's "The Urban Revolution" (Childe 1950; Smith 2009), which, despite its title, was more about sociopolitical organization than it was about population nucleation. Archaeologists have been conflating them ever since, although challenges have been mounting in recent times (e.g., Smith 2003; McIntosh 2005). Jennings and Earle also show a healthy skepticism for "revolutions" generally, the idea that past societies would acquiesce to rapid and radical social change; archaeological revolution is another legacy of Childe's whose time has passed.

One shouldn't entirely throw the baby out with the bathwater, however. The "urban state" is a recurring combination of settlement type and political form. It gets a lot of attention from archaeologists because it is highly visible (much easier to locate and excavate than, for example, the mobile court of a nomadic confederacy). Furthermore, early urban states appear to Western archaeologists as the first steps in the development of our own societies, hence the archaeology of our own origins. It is important to recognize that the urban state is only one possible combination, as Earle's Hawaiian case study illustrates. Nonetheless, it is remarkable how frequently this settlement type and this political formation coincided in the past. An important question to ask is why this combination recurred so frequently. This frequency is at odds with the authors' claim that urban form is actually a deterrent to political centralization.

Jennings and Earle's willingness to reconsider "the city" as a type, and to recognize the significant variation within places that are given that designation, is welcome and refreshing. I want them to bring the same critical reassessment to "the state," a concept which they spend far less time defining. In their argument, the state is "defined narrowly here as a regionally-organized society composed of a ruling class, commoner class, and a highly centralized and internally specialized government;" details are added in a few other places, almost always with "class" as critical element. The authors make important arguments against projecting backwards later political, economic, and social structures, but I am concerned that the use of "class" (and another concept that they invoke less frequently, bureaucracy) in contexts of initial centralization of authority is just such a projection. In the case with which I am most familiar, ancient Mesopotamia, some of the most centralized phases were based on the metaphorical extension of the household to encompass neighborhood, city, and even "state" political organization, in other words, using a kinship model (Schloen 2001; Ur 2014). Instead of the vertical social divisions implied by "class," Bronze Age Mesopotamian society was characterized primarily by horizontal divisions between large households (Stone 2007). Projecting the Bureaucratic State onto it ignores its basis in kinship relations. Early political formations are probably best envisioned in multivariate space, in the same manner proposed for early cities by Cowgill (2004). I would suspect that Tiwanaku and Hawaii were equally diverse and suffer from being lumped into a general category of "the state," especially when such a category is defined by bureaucracy and class. Such a reformulation complicates comparative studies such as Jennings and Earle's. 
In any study of origins, the specter of teleology is always present. It may be lurking in a couple places here. Collective action at Tiwanaku, for example, seems in the present reconstruction to have been motivated by opposition to the centralization of authority, i.e., something that had not yet come into being, and which certainly had not yet attained the negative connotations that "the State" carries today. The authors also state that "People worked hard to create new settlements of larger size," which implies that "people" had envisioned the city and then (collectively?) strived to bring it into existence, despite the fact that such a settlement form was not previously known to them. For these reasons, reconstructions in which initial political centralization and population nucleation are the unintended macro-scale consequences of intentional micro-scale social action are preferable (for my own attempt, see Ur 2014).

Overall, this contribution has done much to stimulate my own thoughts on urban origins and state formation. I find one of the authors' conclusions very difficult to accept, however: the idea that urban social contexts might impede political centralization. Early literate urban polities and more recent states have frequently used urbanization as a means of political control. Geography matters, and populations that are distant will be more difficult to control than populations nearby, as has been well argued by Gil Stein in his "distance parity" model (1999). The Spanish colonial powers ruling over what had once been Tiwanaku understood this as well; their policy of reduccion took low density rural settlements and brought them together in nucleated towns (for a recent coastal Andean discussion see VanValkenburgh 2012). Again there is some danger of teleology here; what mature cities do does not necessarily explain why early cities came about. Nonetheless, the distance parity model goes a long way toward explaining why the urban state has been the rule, rather than the exception, in humanity's 5,000 year urban history.

Childe, V. Gordon. 1950. The Urban Revolution. Town Planning Review 21 (1):3-17.

Cowgill, George L. 2004. Origins and Development of Urbanism: Archaeological Perspectives. Annual Review of Anthropology 33:525-549.

McIntosh, Roderick J. 2005. Ancient Middle Niger: Urbanism and the Self-Organizing Landscape. Cambridge: Cambridge Univ. Press.

Schloen, J. David. 2001. The House of the Father as Fact and Symbol: Patrimonialism in Ugarit and the Ancient Near East, Studies in the archaeology and history of the Levant 2. Winona Lake: Eisenbrauns.

Smith, Michael E. 2009. V. Gordon Childe and the Urban Revolution: A Historical Perspective on a Revolution in Urban Studies. Town Planning Review 80 (1):3-29.

Smith, Monica L. 2003. Introduction: The Social Construction of Ancient Cities. In The Social Construction of Ancient Cities, edited by M. L. Smith. Washington and London: Smithsonian Institution.

Stein, Gil J. 1999. Rethinking World-Systems: Diasporas, Colonies, and Interaction in Uruk Mesopotamia. Tucson: University of Arizona Press.

Stone, Elizabeth C. 2007. The Mesopotamian Urban Experience. In Settlement and Society: Essays Dedicated to Robert McCormick Adams, edited by E. C. Stone. Los Angeles: Cotsen Institute of Archaeology.

Ur, Jason A. 2014. Households and the Emergence of Cities in Ancient Mesopotamia. Cambridge Archaeological Journal 24 (2):249-268. 
VanValkenburgh, Nathaniel Parker. 2012. Building Subjects: Landscapes of Forced Resettlement in the Zana and Chaman Valleys, Peru, 16th and 17th Centuries CE. PhD dissertation, Department of Anthropology, Harvard University. 